2003

\title{
Managing and Monitoring Conflicts of Interest: Empowering the Outside Directors with Independent Counsel
}

James D. Cox

Follow this and additional works at: https://digitalcommons.law.villanova.edu/vlr

Part of the Business Organizations Law Commons

\section{Recommended Citation}

James D. Cox, Managing and Monitoring Conflicts of Interest: Empowering the Outside Directors with Independent Counsel, 48 Vill. L. Rev. 1077 (2003).

Available at: https://digitalcommons.law.villanova.edu/vlr/vol48/iss4/4

This Symposia is brought to you for free and open access by Villanova University Charles Widger School of Law Digital Repository. It has been accepted for inclusion in Villanova Law Review by an authorized editor of Villanova University Charles Widger School of Law Digital Repository. 


\title{
MANAGING AND MONITORING CONFLICTS OF INTEREST: EMPOWERING THE OUTSIDE DIRECTORS WITH INDEPENDENT COUNSEL
}

\author{
James D. Cox*
}

\section{INTRODUCTION}

C

ONFLICTS of interest transactions are ubiquitous within today's cor-

Aporate environment. Executives need to be paid, directors receive compensation for their board service and there frequently are transactions with the corporation's dominant stockholder, to name just a few of the events that regularly pose conflict of interest issues. Most of these transactions are regulated through the template provided by the state conflict of interest statute. ${ }^{1}$ The core feature of such regulation is the non-interested directors' informed review of the suspect transaction. Even when the transaction does not fall neatly within the scope of a conflict of interest statute, the fiduciary obligations courts impose on officers and directors mirror the approach prescribed in the analogous state conflict of interest transaction. In each such setting, the independent director is placed at the vortex of monitoring and, hence, managing conflicts of interest. This Article proposes a modest reform to enhance the ability of independent directors to better manage conflict of interest transactions. By way of background for this reform, this Article explores an important disjunction that exists within corporation law between, on the one hand, the expected role of independent directors in transactions that fall neatly into state conflict of interest statutes and, on the other hand, their role in more generalized forms of conflicts of interest.

The important role that independent directors have in monitoring and managing conflicts of interests reflects our societal commitment to the power of the outside director. Our trust in the monitoring role of the outside director has grown slowly over time. Through most of the 1960s few companies had outside directors; the prevalence of outside directors spread with the corporate governance movement of the 1970 s so that having a majority of a public corporation's board be independent became something of a norm by the 1990s. Today, in the post-Enron era, the outside director continues to be the focus of corporate governance re-

* Brainerd Currie Professor of Law, Duke University. The author is grateful for the research assistance of Mr. Christopher P. Fazekas and Ms. Gitanjali Lakhotia in preparing this Article.

1. For a review of conflict of interest statutes, see generally MOdel BUs. CoRP. Act Ann. \$ 8.61 (3d ed. 1994). See generally James D. Cox \& Thomas Lee Hazen, COX \& HAZEN ON CoRPORATIONS $\$ \$ 10.12-10.17$ (2d ed. 2003) (reviewing history of conflict of interest statutes and judicial construction). 
forms. We have recently seen not only a tightening of NYSE ${ }^{2}$ and NAS$\mathrm{DAQ}^{3}$ listing requirements with respect to independent directors, but also with the recent enactment of the Sarbanes-Oxley Act, ${ }^{4}$ which is the first step toward the federalization of corporate governance norms for outside directors. It is safe to say that expectations for the independent director have never been higher than they are today.

But is the independent director up to the challenges that our expectations have placed before the director? This Article focuses upon a single dimension of this question, namely how we can better empower the independent director to monitor conflict of interest transactions and thereby address this aspect of our rising expectations for the independent director's monitoring function. The prescription here is intended to represent a modest change in boardroom processes. However, this modest step portends significant improvements for the performance of the outside directors to monitor and manage conflict of interest transactions.

\section{Stumbling Down the Path Toward Managing Conflicts OF INTEREST}

Four decades ago Harold Marsh authored his classic treatment of conflict of interest transactions. ${ }^{5}$ The significant contribution of his article is that it disrobed the courts' and legislatures' rapid shift in their approaches to the treatment of conflict of interest transactions. ${ }^{6}$ The

2. See NYSE, Corporate Governance Rule Proposals Reflecting Recommendations from the NYSE Corporate Accountability and Listing Standards Committee, approved by the NYSE Board of Directors August 1, 2002, available at http://www.nyse.com/pdfs/ corp_gov_pro_b_pdf (last visited Mar. 19, 2003) (setting forth thirteen changes in listing requirements related to range of corporate governance matters including requirement that independent directors constitute majority of each listed company's board, more rigorous definition of independence and that all members of audit committee must be independent). Some of the same initiatives are counseled in Preliminary Report of the American Bar Association Task Force on Corporate Responsibility (July 16, 2002), available at http://www.abanet.org/buslaw/ corporateresponsibility/preliminary_report.pdf (last visited Mar. 19, 2003) (calling for mechanisms to empower oversight function of independent directors such as authorizing audit committee to retain its own experts and regular executive sessions among outside directors).

3. See Summary of NASDAQ Corporate Governance Proposals, available at http:// www.Nasdaqnews.com/about/corpgov/corpgovprop0913.pdf (last visited Mar. 30, 2003) (paralleling provisions of NYSE, as well as offering definition of director independence).

4. See generally Sarbanes-Oxley Act, H.R. 3763, 107TH Conc. (2d Sess. 2002). With respect to federalization of corporate governance, consider section 301 of the Act which calls for an independent audit committee, specifies duties for the audit committee, notably the appointment, compensation and termination of the firm's outside accountant and requires that the audit committee have resources to engage such experts as it needs to discharge its duties.

5. See generally Harold Marsh, Jr., Are Directors Trustees? Conflict of Interest and Corporate Morality, 22 Bus. LAw. 35 (1966).

6. See id. at 36 . 
movement must have a beginning place, and Marsh places that near the end of the 19th Century:

In 1880 it could have been stated with confidence that in the United States the general rule was that any contract between a director and his corporation was voidable at the instance of the corporation or its shareholders, without regard to the fairness or unfairness of the transaction. . . [ [I]t mattered not the slightest that there was a majority of so-called disinterested directors who approved the contract. ${ }^{7}$

The reasons for the historical skepticism of self-dealing transactions are many. There is the somewhat formalistic view that the corporation and, therefore its shareholders, are entitled to the impartial judgment of all of its directors. $^{8}$ The presence of a conflict of interest was therefore seen as interdicting this belief. Moreover, the difficulty of detecting and measuring the influence that the interested director may wield, directly or indirectly, on the disinterested directors justified a prophylactic prohibition. ${ }^{9}$ A related concern is that expressed in an early Maryland Supreme Court decision:

[That when there is a transaction between a corporation and one of its directors] the remaining directors are placed in the embarrassing and invidious position of having to pass upon, scrutinize and check the transactions and accounts of one of their own body, with whom they are associated on terms of equality in the general management of all the affairs of the corporation. ${ }^{10}$

The rest of the story is well known. Because conflicts of interests are endemic to the commercial setting that the corporation calls home, pragmatism prevailed over what was believed unsubstantiated fears of selfinterested behavior. Courts seriously tempered their earlier approaches to conflict of interest transactions. Such judicial moderation was followed by legislative initiatives that set forth the template that prevails today for the regulation of conflict of interest transactions. This is captured nicely in Marsh's next snapshot of history:

It could have been stated with reasonable confidence in 1910 that the general rule was that a contract between a director and his corporation was valid if approved by a disinterested majority of his fellow directors and was not found to be unfair or fraudulent by the court if challenged. ... One searches in vain in the decided cases for the reasoned defense of this change in legal

7. Id. at $36-37$.

8. See id. at 37.

9. See id.

10. Id. at $37 \mathrm{n} .8$ (quoting Cumberland Coal \& Iron Co. v. Parish, 42 Md. 598, $606(1875))$. 
philosophy, or for the slightest attempt to refute the powerful arguments which had been made in support of the previous rule. ${ }^{11}$

The "modern" legislative and judicial approach to conflict of interest transactions operates with a good deal of ambiguity. Most statutes provide a tripartite proscription that calls for either impartial approval by either the shareholders or the director, or the transaction passing a fairness standard. The ambiguity of this approach exists at several levels. ${ }^{12}$ The most dramatic concern is whether compliance with the statute merely affects the burden of proof but does not insulate the transaction entirely from judicial scrutiny. That is, there is ample case authority that even though there may have been technical compliance with, for example, the stockholder approval prong of the state conflict of interest transaction, the court can still entertain an assault on the transaction on general fairness considerations. ${ }^{13}$ Lower orders of ambiguity surround just what constitutes "good faith" approval, as called for by the statute, as well as what type of interest removes the approving person from being deemed sufficiently independent to be included in the ratifying body. ${ }^{14}$

11. Id. at 39-40. The next important dateline in Marsh's treatment is fifty years later.

By 1960 it could be said with some assurance that the general rule was that no transaction of the corporation with any or all of its directors was automatically voidable at the suit of a shareholder, whether there was a disinterested majority of the board or not; but that the courts would review such a contract and subject it to rigid and careful scrutiny, and would invalidate the contract if it was found to be unfair to the Id. at 43 . corporation.

12. See, e.g., Cal. Corp. Code $\$ 310$ (West 1977); Del. Gen. Corp. L. $\$ 144$ (2001); N.Y. Bus. CoRP. LaW $\S 713$ (McKinney 1971); Model Bus. Corp. Act AnN. $\$ \S 8.61-8.63$ (2002).

13. See generally Fliegler v. Lawrence, 361 A.2d 218 (Del. 1976) (determining that compliance shields transactions solely from conflict of interest issue but inquiries into inherent fairness may continue); Mary A. Jacobson, Note, Interested Director Transactions and the (Equivocal) Effects of Shareholder Ratification, 21 DeL. J. CoRP. L. 981 (1996) (reviewing wide-ranging approaches to level of judicial review following approval by disinterested decision maker). The leading case for the proposition of a fairness inquiry is Remillard Brick Co. v. Remillard-Dandini Co., 241 P.2d 66, 77 (Cal. Ct. App. 1952) (finding that though there was approval by majority of sharesactually proxies held by interested officers-court will entertain challenge to transaction's fairness).

14. See, e.g., Kahn v. Tremont Corp., 694 A.2d 422, 433 (Del. 1997) (finding that substantial business relationships, rare attendance at meetings and apathy in face of conflict of interest transactions are not consistent with being independent); Groves v. Rosemound Improvement Ass'n, 490 So. 2d 348, 350-51 (La. Ct. App. 1986) (concluding that approval at meeting called without notice by dominant stockholder to approve transaction with him lacked good faith); Miller v. Magline, Inc., 256 N.W.2d 761, 775 (Mich. Ct. App. 1977) (reaching questionable result that serial approval by directors of their respective salaries as officers satisfied statute so that plaintiff had burden of proof thereafter of establishing whether compensation was excessive). 
Ambiguity is not a prized commodity to the transactional lawyer. When this observation is joined by the fact that most corporate statutes, and the Model Business Corporation Act in particular, are the product of transaction-oriented lawyers, one has the beginnings of a good understanding of the derivation of the most recent iteration of conflict of interest transactions, the 1989 amendments to the Model Business Corporation Act. ${ }^{15}$ In broad overview, the drafting philosophy underlying the 1989 amendments was to provide a bright-line test to identify what is a director conflict of interest transaction ${ }^{16}$ and to provide a safe harbor to insulate the transaction from any challenge when the conditions for satisfying the safe harbor are satisfied. The amendments seek certainty, in part, but only in part, by their exacting specifications with respect to the disclosures that must accompany the disinterested approval process, the definition of independence and, of course, what falls within the provision. However, statutory language is never free of ambiguity. The true safe harbor protection arises not by the mapping of its shores, but by the forthright statutory command that if its provisions are met a court may not thereafter enter the waters. The statute bluntly provides that a "director's conflicting interest transaction may not be enjoined, set aside or give rise to an award of damages or other sanctions" if the approval process set forth in the statute has been satisfied. ${ }^{17}$

The focus in this Article is neither to question the Model Act's approach with that found in state legislative enactments nor to quibble with the various judicial approaches to interpreting state conflict of interest provisions. The message of the above review of history is that in a very short time the law has moved from prohibiting conflict of interests to a philosophy that conflicts of interest are instead to be managed. Central to this development, at least for most of the second half of the last century, has been the independent director.

15. See generally Douglas M. Branson, Assault on Another Citadel: Attempts to Curtail the Fiduciary Standard of Loyalty Applicable to Corporate Directors, 57 FORDHAM L. REv. 375 (1988) (finding that amendment too narrowly defines conflict of interest and weakens fiduciary protections that otherwise would apply); Peter E. Kay, Comment, Director Conflicts of Interest Under the Model Business Corporation Act: A Model for All States?, 69 WASH. L. REv. 207 (1994) (concluding statute provides less regulation than earlier provisions of Model Act).

16. See Model Bus. Corp. ACt ANN. $\S \S 8.61-8.63$. Of note is that the 1989 amendment to the Model Act, much like its earlier iterations, applies only to director conflict of interest transactions. Many other statutes, among them California, Delaware and New York, are not so limited so that they apply to both officer and director transactions. The Model Act instead defers to general fiduciary principles with respect to officer conflict of interest transactions where the review and approval of an independent decision maker, most likely the independent directors, would be of central importance in any challenge to the transaction.

17. Model Bus. Corp. Act Ann. $\$ 8.61$ (b). 


\section{Playing Within Yourself}

Dirty Harry tells us that "a man has to know his limitations" and Bobby Knight over his career has turned raw talent into great basketball players by admonishing his recruits to "play within yourself." Both bits of wisdom apply equally to the governance system that has evolved for the American public company. It can be safely said that the hierarchy of the public company is comprised of doers and watchers. The latter are the outside directors whose central task is to monitor the performance of senior management, most particularly the chief executive officer (CEO). Limitations of time that the independent directors have to devote to their boardroom obligations, as well as that they are not engaged in the company's affairs on a daily basis, necessarily require that they are dependent upon reports and efforts of others-senior management, consultants, attorneys-for the information vital to discharging their monitoring functions. ${ }^{18}$ Such reliance, however, is not without limit. In the words of the Model Business Corporation Act, such reliance is permitted, provided the director "does not have knowledge that makes reliance unwarranted." 19

It is, therefore, fairly well understood that the successful discharge of the outside directors' monitoring role is dependent on the directors being independent from management. ${ }^{20}$ But independence alone is not enough. The outside directors, however independent, must nonetheless have before them adequate and objective information relevant to management's stewardship if they are to be true monitors of management. In the context of the firm's financial performance and position, the trustworthiness of the information flowing to the board is reinforced by the certification function carried out by the firm's independent auditors. In other contexts, there is rarely an independent certification provider similar to that for the firm's financial statements with the effect that outside directors are wholly dependent upon those they are to monitor for the information needed to successfully discharge their monitoring function. ${ }^{21}$ But, with respect to the central question of the managers' leadership, the finan-

18. See, e.g., id. $\$ 8.30(\mathrm{e})(1)-(3)$.

19. Id. $\S 8.30$ (d). Collateral points in the equation for a director to have breached her duty in so relying are that the director did not make sufficient inquiry into the matter as was reasonably required under the circumstances, or that there were facts before the director suggesting that perhaps reliance upon the report or opinion of another was not reasonable under the circumstances and failing to investigate further to satisfy herself that reliance would be appropriate. See id. $\$ \$ 8.31$ (a) (2) (ii) (B), 8.31 (a) (2) (iv).

20. See Melvin Aron Eisenberg, Legal Models of Management Structure in the Modern Corporation: Officers, Directors, and Accountants, 63 CAL. L. Rev. 375, 404 (1975) ("The problem of corporate practice is that while effective performance of the monitoring function is conditioned on monitors who are (i) independent of those who are monitored, and (ii) capable of obtaining adequate and objective information concerning management, in the case of most boards neither condition is fulfilled.").

21. See id. (noting that even information certified by outside accountants arises initially from managers). 
cial information certified annually by the outside accounts covers most of the story. A natural place for expanding the outside directors' resort to independent information sources would be transactions where, to use the language of the Model Act, their reliance on managers' representations, reports or opinions is, in light of the circumstances "unwarranted."22

\section{Relationships That Make Reliance UnwarRanted}

In satisfying their monitoring tasks the outside directors must not have cause to believe the sources informing their judgment are not trustworthy. Just what would so qualify as a source being relied upon by the directors is a matter in which appearances to the outside observer are important. Among modern cases, the most developed body of law on the topic of what relationships so qualify the outside directors' ability to rely on a third person as to deny deference to their actions being independently arrived at, occurs in the context of special litigation committees.

The special litigation committee has evolved over the last quarter of a century as a medium for the corporate interest served by a derivative suit's prosecution to be expressed with the full force of the board of directors. ${ }^{23}$ Most frequently, the special litigation committee arises when a majority of the board of directors is sufficiently implicated in the substance of the derivative suit that the full board of directors is so disabled by its members' self-interest as to be an untrustworthy spokesperson regarding the costs and benefits of the derivative suit. Even though the full board may be incapacitated to speak for the corporation on such matters, it is widely recognized that it may select from its members those who are not so conflicted and assign to them the task of examining the suit's merits, benefits and costs. Furthermore, matters of efficiency may commend this task to a subset of the board's directors even in cases when a majority of the board does not suffer a disabling self-interest that renders their judgment untrustworthy. Thus, committees of independent directors, meaning those not so directly implicated in the derivative suit as to be deemed self-interested in the outcome, are recognized by statute ${ }^{24}$ and case law as appropri-

22. See Model Bus. Corp. Act Ann. $§ 8.30$ (d).

23. See generally John C. Coffee, Jr. \& Donald E. Schwartz, The Survival of the Derivative Suit: An Evaluation and a Proposal for Legislative Reform, 81 Colum. L. Rev. 261 (1981) (critiquing early decisions reviewing recommendations of special litigation committees and proposing review procedure that became starting point for reforms introduced by American Law Institute (ALI)); James D. Cox, Searching for the Corporation's Voice in Derivative Suit Litigation: A Critique of Zapata and the ALI Project, 1982 Duke L.J. 959 (examining derivation of special litigation committee and indeterminancy of standards for judicial review in Delaware and proposed by ALI).

24. See generally Model Bus. Corp. ACt ANN. $§ 7.44$ (a) (b) (authorizing dismissal of derivative suit upon recommendation of independent committee of board if recommendation is arrived at "in good faith conducting a reasonable inquiry"). 
ate mediums to assess and report to the court regarding whether the derivative suit should be continued, settled or dismissed. ${ }^{25}$

In making their assessment, the outside directors who constitute the special litigation committee rely heavily on their advisors, most importantly the committee's counsel who is sometimes joined by other consultants. In the special litigation committee setting, the question of the committee members' independence is directly linked to the relative independence of its counsel. Einhorn $v$. Culea ${ }^{26}$ best summarizes how the committee's counsel fits into the equation for assessing the committee's overall independence: "Courts should be more likely to find a special litigation committee independent if the committee retains counsel who has not represented [the suit's] individual defendants or the corporation in the past." ${ }^{27}$ Thus, the committee's recommendation is entitled to more deference when it is represented by counsel who has not previously represented the corporation. Such earlier, and particularly on-going, representation of the corporation raises questions regarding independence and, hence, possible biasing of the information and advice counsel may provide the committee. ${ }^{28}$ Certainly there is cause for pause when there is reason to

25. Such recognition is not without its fair share of skepticism regarding the committee's members' ability to put aside subtle social and psychological biases that may distort their judgment. See generally James D. Cox \& Harry L. Munsinger, Bias in the Boardroom: Psychological Foundations and Legal Implications of Corporate Cohesion, 48 LAW \& Contemp. Probs. 83 (1985) (examining variety of social forces that lead to group cohesion that can bias committee members against derivative suit regardless of its merits); George W. Dent, Jr., The Power of Directors to Terminate Shareholder Litigation: The Death of the Derivative Suit, 75 Nw. U. L. Rev. 96, 111 (1980) ("When charges are leveled against a majority of the directors, the pressures on even nonimplicated directors are so great as to justify a conclusive presumption they cannot independently investigate and weigh the facts and reach a conclusion that is in the interest of the corporation.").

26. 612 N.W.2d 78 (Wis. 2000).

27. Id. at 90 . For an earlier expression of skepticism regarding the questionable independence of the firm's established outside counsel, see Joseph W. Bishop, Jr., Silting Ducks and Decoy Ducks: New Trends in the Indemnification of Corporate Directors and Officers, 77 YALE L.J. 1078, 1080 (1968) (stating that outside counsel is too financially dependent on management to be deemed disinterested).

28. See, e.g., In re Par Pharm., Inc., 750 F. Supp. 641, 647 (S.D.N.Y. 1990) (failure to retain counsel independent from derivative suit corporation deprives committee of its independence).

Due to the generality with which ethical rules are written, there is marked opacity in the American Bar Association's (ABA) strictures on whether such a situation involves a disabling conflict of interest. For example, since the lawyer's client is the corporation, superficially there is no conflict if the lawyer advises the special litigation committee and has previously represented the corporation more generally. See Model Rules of Prof'l Conduct R. 1.7(a)(2001). The more direct concern here is whether his or her representation of the committee is seen as jeopardizing a private interest the lawyer has in continuing to represent the corporation, which can be seen as falling into the broader proscription of the Model Rule: "A lawyer shall not represent a client if the representation of that client may be materially limited by the ... lawyers own interests, unless: (1) the lawyer reasonably believes the representation will not be adversely affected; and (2) the client consents after consultation." Id. R. 1.7(b). 
believe that the committee's counsel's ability to retain future corporate business is dependent upon the decisions of the very executives the committee, through its counsel, is investigating. ${ }^{29}$ Because past is so predictive of prologue, an attorney who has previously enjoyed a professional relationship with the corporation poses just such a risk. The attorney's close scrutiny of, for example, the $\mathrm{CEO}$ and any resulting stinging condemnations or insinuations embodied in the committee's report are unlikely to place the attorney's firm in good standing with the CEO when the executive may later be required to choose who should represent the company in future matters. For this reason, and as reflected in Einhorn, courts minimally recognize that independence of counsel is a desideratum and is best achieved when the committee's counsel has not previously represented the corporation. ${ }^{30}$

A related provision is Model Rule 1.13 which provides that the corporate lawyer's client is the corporation, not its senior management. This raises interesting ethical issues in the derivative suit setting.

Most derivative actions are a normal incident of an organization's affairs, to be defended by the organization's lawyer like any other suit. However, if the claim involves serious charges of wrongdoing by those in control of the organization, a conflict may arise between the lawyer's duty to the organization and the lawyer's relationship with the board. In those circumstances, Rule 1.7 governs who should represent the directors and the organization.

Id. $\mathrm{R}$. $1.7 \mathrm{cmt}$. The above position is complemented by ABA Model Code Canon 518, Ethical Considerations and Disciplinary Rules, which provides that a lawyer retained by a corporation owes his duty to the corporation and not to a stockholder, director or officer or other person connected with the entity and that the lawyer's judgment should not be impaired by the personal desires of any one person within the organization.

29. However, the fact that the law firm representing the committee was required to contribute toward the settlement of a private suit in which the plaintiffs were represented by the same counsel as in the derivative suit was not deemed to tarnish the independence of the committee. See Kaplan v. Wyatt, 499 A.2d 1184, 1190 (Del. 1985) (noting that this matter was raised ten months after committee had rendered its report).

30. See, e.g., Drilling v. Berman, 589 N.W.2d 503 (Minn. Ct. App. 1999) (linking committee's good faith and independence with absence of ties its counsel had to corporation and its experience in representing special litigation committees). The most rigid holding on this point is In re Oracle Securities Litigation, 829 F. Supp. 1176,1189 (N.D. Cal. 1993) (rejecting settlement approved by committee of directors on grounds it did not receive advice that was independent). However, Oracle involved a committee's reliance on in-house, rather than outside, counsel, so that the general counsel's day-to-day reporting relationship to the suit's defendants makes an especially strong case for doubting his independence. But see Cutshall v. Barker, 733 N.E.2d 973, 980-81 (Ind. Ct. App. 2000) (holding that independence of committee was not tainted because its law firm also represented corporation and law firm had commenced its representation of corporation after derivative suit's commencement). The result reached in Cutshall fails to understand the significance of counsel's past representation of the corporation. The attorney's advice may be compromised, not because of past professional representation of the corporation through the suit's defendants, but instead by the expectation of future representation. The past representation is probative of a possible conflict of the 
The courts' treatment of the independence of counsel in the context of the special litigation committee is complementary to their position with respect to the derivative suit's defendants and the corporation being represented by the same counsel. Because it is the corporation's cause of action that is asserted in the derivative suit, it is well understood that the corporation is a necessary party in the action. At least in the non-frivolous suit, its interests are adverse to those of the suit's real defendants. Questions therefore abound throughout the suit's life regarding whether to seek to derail the suit by settlement or by impaneling a special litigation committee, and perhaps even pressing it more aggressively by having corporation's counsel take over the suit. Because of such potential conflicts, courts customarily require that the corporation and the derivative suit's real defendants not be represented by the same counsel. ${ }^{31}$ More importantly for the purposes of the thesis advanced here is that the courts require that the corporation obtain new counsel, thus permitting the firm with an on-going relationship with the company to represent the suit's defendants, but not the corporation. ${ }^{32}$ This result again reflects the belief that the advice that counsel might provide the corporation in such a case may be seriously compromised and the on-going relationship with the company is not solidified by encouraging the corporation to "go for it."

The linkage between, on the one hand, the relative independence of counsel from senior management and, on the other hand, the relative independence of directors is also apparent outside the derivative suit context. For example, challenges of fairness of merger transactions sometimes include claims that the approving directors acted improperly by failing to obtain financial or legal advisors who were independent from the senior management team that was recommending the transaction. Those claims are without salience and, therefore, easily dismissed when

attorney only because it may indicate an expectation of future representation of the corporation, which would be jeopardized if the attorney were overly zealous.

31. See generally Bell Atlantic Corp. v. Bolger, 2 F.3d 1304 (3d Cir. 1993) (holding dual representation improper when suit involves "serious charges of wrongdoing"); Lewis v. Shaffer Stores Co., 218 F. Supp. 238 (S.D.N.Y. 1963) (stating that corporation and individual directors named in suit cannot share the same counsel); $c f$. generally Int'l Bhd. of Teamsters v. Hoffa, 242 F. Supp. 246 (D.D.C. 1965) (holding that union and its officers charged with wrongdoing in suit brought on behalf of union cannot be represented by same attorney).

32. See, e.g., Musheno v. Gensemer, 897 F. Supp. 833, 887-88 (M.D. Pa. 1995) (requiring new counsel when claims involve serious charges of wrongdoing); Messing v. FDI, Inc., 439 F. Supp. 776 (D.N.J. 1977) (reasoning that even when negligent misconduct alleged on part of managers, suit involves conflicts of interest between suit's real defendants and corporation such that latter should retain new counsel); Cannon v. U.S. Acoustics Co., 398 F. Supp. 209, 216 (N.D. Ill. 1975), aff'd in relevant part per curiam, 532 F.2d 1118, 1119 (7th Cir. 1976) (“[I]n a derivative suit the better course is for the corporation to be represented by independent counsel from the outset, even though counsel believes in good faith that no conflict of interest exists."). 
the merger is by all measures an arms-length transaction. ${ }^{33}$ In this context, the directors' approval enjoys the protective benefits of the business judgment rule; their failure to seek additional advisors is a matter committed to their better judgment. However, when the merger involves the acquisition by the dominant stockholder, or a merger with an entity in which senior management will have a significant ownership interest, sensitivities regarding independence arise and the judicial expectations for the approving directors change. In this self-dealing context, the level of involvement of independent advisors-including lawyers-with the outside directors is an important consideration regarding both the directors' independence and good faith in approving the transaction. ${ }^{34}$ Similar to the approach taken in the special litigation committee context, there is no fixed requirement that the directors called upon to approve a self-dealing acquisition be advised by those who have no historical relationship with the dominant stockholder or senior management. Nevertheless, the presence of such independent advisors weighs heavily in the balance in the courts' scrutiny of the transaction under the "entire fairness" standard. ${ }^{35}$ The concern in the self-dealing context is that the advice by investment bankers, accountants or lawyers who have a historical relationship with the controlling stockholder, senior management or both, may well be compromised by not only their prior relationship to the managers but their desire to continue their relationship following the acquisition.

The link between director independence and the independence of their advisors from management is sharpest in the context of the Investment Company Act of $1940 . .^{36}$ It is well understood that the impetus for the Act is that investment companies are best understood not solely by

33. See, e.g., Cottle v. Storer Communication, Inc., 849 F.2d 570, 578 (11th Cir. 1988) (dismissing claim of price inadequacy premised on failure of management to obtain new investment advisor to advise it regarding third party's buyout offer); Am. Insured Mortgage Investors v. AIM Capital Mgmt., [1990-1991 Transfer Binder] Fed. Sec. L. Rep. (CCH) If 95,730 (S.D.N.Y. Nov. 26, 1990); Torchmark v. Bixby, 708 F. Supp. 1070, 1082 (W.D. Mo. 1988) (stating board may reject hostile bid for control without first retaining outside investment advisers); Lewis v. Honeywell, Inc., [1987-1988 Transfer Binder] Fed. Sec. L. Rep. (CCH) II 93,565 (Del. Ch. July 28,1987 ) (although evaluation by outside advisers of hostile takeover bid is probative, it is not essential to establish or support informed business judgment).

34. See, e.g., Hanson Trust PLC v. SCM Acquisition, Inc., 781 F.2d 264, 277 (2d Cir. 1986) (holding directors failed to exercise reasonable care in approving buyout of firm by entity that would be fifteen percent owned by senior management and who was advised by same investment banker as board was relying upon in approving buyout and protective lockup arrangements); T. Rowe Price Recovery Fund L.P. v. Rubin, 770 A.2d 536, 546-47, 552-53 (Del. Ch. 2000) (merger of firm into affiliated corporation was preliminarily enjoined where showing was that board was not advised by counsel or investment bank that was independent from controlling stockholder).

35. See Rubin, 770 A.2d at 552-53 (fair dealing component of "entire fairness" standard not satisfied when acquired company's board was represented by same counsel and investment banker as represented controlling party of corporation and its merger partner).

36. See 15 U.S.C. $\$ 80 \mathrm{a}-1(2000)$. 
what they do-superintend an investment portfolio on behalf of passive owners-but by what they are, a web of highly incestuous service providers, each of whom stand to profit regardless of the portfolio's performance. To put it bluntly, the steady diet, if not the exclusive fare, of the board of directors of an investment company is their approval of conflict of interest transactions. In 1940, Congress addressed issues posed by the investment companies by proscribing a wide range of possible transactions that were either prohibited outright or to be subjected to close regulation pursuant to rules adopted by the Securities and Exchange Commission. ${ }^{37}$ In the end, the proscriptions were so broad that the regulatory net folded over the incestuous web visited significant transactions costs and lost opportunities. To alleviate some of the regulatory friction created by the Act and its rules, the SEC crafted numerous safe harbors for a variety of conflict of interest transactions. Central to each safe harbor is the need for independent director approval of the conflict of interest transaction. In early 2001, the SEC tightened its safe harbor provisions by conditioning their availability on, among other factors, the independent directors being advised by "independent counsel." 38 After the 2001 amendments, the SEC's conflict of interest safe harbors are no longer available unless counsel that is independent from the fund's investment advisor advises the approving independent directors. The overriding policy of the 2001 amendments is that "conflicts involved in the transactions and arrangements permitted by the exemptive rules make it critical that independent directors, when they seek legal counsel, be represented by persons who are free of significant conflicts of interests that might affect their legal advice." 39 Even though the SEC stops short of prescribing the criteria for an attorney to qualify as an independent counsel, a central concern in its release adopting the independent counsel requirement is that the counsel

37. See 17 C.F.R. $\S 270$ (2002).

38. See Role of Independent Directors of Investment Companies, 66 Fed. Reg. 3734 (Jan. 16, 2001) (to be codified at C.F.R. pts. 239, 240, 270 and 274) (adopting amendments to rules of Investment Company Act regarding availability of certain safe harbor provisions for conflict of interest transactions).

39. Id. at 3737. More generally, even before the 2001 amendments, the courts with some frequency emphasized the importance of the outside directors being advised by independent counsel when there was before the court a challenge to a transaction between the fund's advisors and the fund. Cases relied upon by the SEC in its release were Schuyt v. Rowe Price Prime Reserve Fund, Inc., 663 F. Supp. 962, 965, 982, 986 (S.D.N.Y. 1987), aff d, 835 F.2d 45 (2d Cir. 1987) (emphasizing that board was represented by its own counsel throughout) and Gartenberg $v$. Merrill Lynch Asset Mgmt., Inc., 528 F. Supp. 1038, 1064 (S.D.N.Y. 1981) (noting board was represented by counsel independent from fund's advisor). See Role of Independent Directors of Investment Companies, 66 Fed. Reg. at 3738.

Before the SEC amended its rules in 2001, a blue ribbon task force for the investment company industry set forth a variety of best practices for investment companies including that independent directors have qualified counsel who is independent from the fund's investment advisor. See Investment Co. Inst., The Advisory Group on Best Practices for Fund Directors, at http://www.ici.org/issues/dir/ index.html (Mar. 13, 2003) (setting forth fifteen recommended best practices). 
not be compromised by an historical relationship with the fund's advisor. ${ }^{40}$

\section{Conflicts of Interests and Independence of Counsel}

The preceding Parts reflect some fairly modern developments that enhance the oversight role of the outside director. Whether under state law in the context of derivative suit issues and entire fairness inquiries for mergers, or in the availability of safe harbors under the Investment Company Act, an important factor in gauging the independence of directors is the relative independence of those advising the director. This factor not only has great intuitive appeal, but within the context of the public company, has great practical appeal. The outside director suffers from a serious informational disadvantage because the director comes from outside the firm whose performance the director is to monitor, and has limited time to probe deeply into the firm's information systems. The director's vision of the pros and cons of an item placed before the director is only as sharp as the lens the director peers through. Because of the aforementioned information disadvantages, the lens through which the director

40. The relevant part of the definition of "independent legal counsel" is: A majority of the disinterested directors reasonably determine . . . that any representation by the person of the company's investment adviser, principal underwriter, admịnistrator . . . or any of their control persons, since the beginning of the fund's last two completed fiscal years, is or was sufficiently limited that it is unlikely to adversely affect the professional judgment of the person in providing legal representation to the disinterested directors.

17 C.F.R. \$ 270.0-1(a)(6)(i) (A) (2002). The release further states that the Commission does "not believe that . . . a lawyer whose firm simultaneously represents the fund's advisor and independent directors in connection with matters as important to fund shareholders as the negotiation of the advisory contract or distribution plan, or other key areas of conflict between the fund and its adviser, is an 'independent legal counsel.' See Role of Independent Directors of Investment Companies, 66 Fed. Reg. at 3739.

The public concern that lawyers are compromised by their economic relationship to the senior management team is further manifested by the inclusion of Section 307 of the Sarbanes-Oxley Act of 2002, amending 15 U.S.C. $\$ 7245$ (2000), calling upon the SEC to draft professional rules of conduct for attorneys representing public issuers when the attorney is aware the issuer or its personnel are engaged or about to engage in fraudulent conduct. The sentiment driving this provision is reflected by then SEC Chairman Harvey Pitt: "Lawyers for public companies represent the company as a whole and its shareholder-owners, not the managers who hire and fire them. This should be self-evident, but recent events indicate some corporate lawyers have lost sight of this axiom, a form of professional blindness that isn't new." Harvey L. Pitt, Speech by SEC Chairman: Remarks Before the Annual Meeting of the American Bar Association's Business Law Section, (Aug. 12, 2000), at www.sec.gov/news/speech/spch579.htm. But see Remarks of Ms. Victoria Schonfeld, Mutual Fund Regulation in the Next Millennium Symposium Panels: I. Fund Governance, 44 N.Y.L. ScH. L. REv. 431, 449 (2001) ("[I]t is more important that you have experienced counsel than that you have truly independent counsel. Good experienced counsel is not likely to be swayed by the fact that their corporate partners across the country are doing deals for subsidiaries of the management company."). 
sees the transaction is generally not that of the director's own making; the information reaching the director has been filtered in most instances by management. To be sure, there are some important checks and balances in the process. The foremost check and balance is the important role that the outside auditors play in refereeing the reports of the firm's financial performance and position. Though there is always the fear that managerial self-interest will corrupt the information that reaches the board, absent notice to the contrary, boards are entitled to rely upon reports prepared by managers and their stewards unless the directors are aware of circumstances that make such reliance unreasonable.

The standard approach of trusting management to fairly present all the information needed for the board to discharge its responsibilities is, as stated above, not without qualifications. In important areas posing a direct conflict of interest, reliance upon the managers, or those who may be beholden to the managers, is a consideration in a court's review of whether the directors are independent. Under the Investment Company Act, director independence for self-dealing transactions requires the presence of independent counsel. ${ }^{41}$ It would seem a small step from where the law is today in these areas if good corporate governance practices were to build slightly upon the law's present command for those advising the independent directors to be independent when the transaction involves a significant conflict of interest with senior management or the controlling stockholder. This is the core of the modest proposal advanced here. There is reason to believe it would have a significant impact in some instances.

The suggestion advanced here is not nearly as sweeping as that put forth thirty years ago by former Supreme Court Justice Arthur Goldberg. ${ }^{42}$ Mr. Justice Goldberg, in connection with his resignation from several corporate boards, complained that he was unable to stay adequately informed and therefore could not responsibly carry out his functions as a director. ${ }^{43}$ His prescription for this ill was that outside directors of public companies have "a small staff of experts who would be responsible only to the board and would be totally independent of management control."44 Rather than have an established group of permanent staffers whose task is to enrich the information flows to the board, it would be wiser, less disruptive and more empowering if, as a matter of practice, outside directors retained independent advisors whenever a significant conflict of interest transaction involving a manager or substantial stockholder comes before the at 3737 .

41. See Role of Independent Directors of Investment Companies, 66 Fed. Reg.

42. See Arthur J. Goldberg, Debate on Outside Directors, N.Y. Times, Oct. 29, 1972 $\$ 3$, at 1 (advocating that board establish committee of overseers of outside directors).

43. See id.

44. Id. at 3 . 
board. The American Law Institute (ALI) advances some authority for this approach in its Corporate Governance Project. ${ }^{45}$ The ALI provides:

The directors of a publicly held corporation who have no significant relationship with the corporation's senior executives should be entitled, acting as a body by the vote of a majority of such directors, to retain legal counsel, accountants, or other experts, at the corporation's expenses, to advise them on problems arising in the exercise of their functions and powers if:

(a) Payment of such expense is authorized by the board; or

(b) A court approves an application for payment of such expense. . . . 46

It should be noted that the ALI provision authorizing resort to outside experts is limited to public corporations. ${ }^{47}$ The practice recommended here is not so limited. Furthermore, whereas the ALI is enabling, what is suggested here is a firm call for the independent directors to engage outside experts, most importantly independent counsel, as a matter of custom whenever there is a significant conflict of interest transaction. Such a practice, in contrast to the ALI approach, assures that the directors will receive the information they need to effectively manage conflicts of interest transactions.

The proposal advanced here is not in conflict with, but rather is complementary to, the highly controversial provision included in the recently enacted Sarbanes-Oxley Act. ${ }^{48}$ Section 307 of the Sarbanes-Oxley Act calls upon the SEC to adopt rules "requiring an attorney to report evidence of a material violation of securities law or breach of fiduciary duty or similar violation by the company[,]" officers or other agents. ${ }^{49}$ The order of to whom the attorney is to report his warning begins with the firm's chief legal counsel but can extend to the board of directors or one of its committees. ${ }^{50}$ At publication, the SEC rules pursuant to this provision were still in the proposal stage, but as proposed, the rules included a requirement for the attorney to withdraw noisily from representation if not satisfied that the corporation, after being informed of the misconduct, failed to act appropriately. ${ }^{51}$

45. See 1 Principles of Corporate Governance: Analysis and RecommendaTIONS \$3.04 (A.L.I. 1994) (setting forth rights of directors to retain outside advisors).

46. Id.

47. See id. (stating "directors of a publicly held corporation") (emphasis added).

48. See Sarbanes-Oxley Act of 2002, Pub. L. No. 107-204 § 307, 116 Stat. 745.

49. See id.

50. See id. (stating that material violation should first be reported to chief legal counsel and if counsel does not appropriately respond, violation should be reported to audit committee of board of directors of issuer).

51. See Implementation of Standards of Professional Conduct for Attorneys, 67 Fed. Reg. 71,670, 71,673 (proposed Nov. 21, 2002) (containing SEC proposals to carry out rules called for by Section 307 ). 
A desired effect of the professional standard called for by SarbanesOxley is to enhance the flow of information to not only senior management but frequently to the board of directors when the attorney discovers as part of the attorney's engagement that, for example, an officer has not fully disclosed all facts relevant to assessing the corporation's interest with respect to a transaction. The next Part illustrates that Enron's outside lawyers, even though harboring serious doubts about whether certain transactions were being properly reported, did not share their doubts with the directors, even though the transactions were being closely scrutinized by the board because they were known to involve self-dealing by senior managers. Even in light of the change in professional standards ushered in by Sarbanes-Oxley, the board of directors in self-dealing transactions should still regularly seek the advice of independent counsel.

The professional requirements of Sarbanes-Oxley only come into play for attorneys "appearing and practicing" before the SEC.52 If, for example, the transaction does not directly involve an SEC-based disclosure issue, the issuer is not a reporting company or the self-dealing transaction does not reach the level of materiality to command disclosure, this SECbased professional standard would appear to not apply. Moreover, the suggestion advanced here is to accord the board of directors, when addressing officer conflict of interest transactions, assurance of a searching inquiry by independent counsel as a prelude to counsel advising the directors. This is not the orientation of the SEC's professional responsibility standard. The SEC's standard requires action on the part of the attorney who becomes aware of a securities violation or breach of fiduciary duty; the standard does not require, or even encourage, the attorney to closely scrutinize transactions for the purpose of learning whether there is such a breach. Indeed, attorneys who wish not to jeopardize their relationship with the senior managers may well find it advisable, in light of the SEC professional responsibility standard, to content themselves with simply "papering the deal," and not to dig too deeply into the corporation's business justifications for fear this might well trigger their obligations under the SEC's professional responsibility standard. And, most significantly, under the proposal advanced here, the directors and the firm benefit not only from information disclosed to them that rises to the level of a "[securities violation] or breach of fiduciary duty or similar violation," 53 but also from information that simply bears on a range of risks and tradeoffs posed by the transaction. ${ }^{54}$ Just as in other areas reviewed earlier, where the courts recognize that there is a clearer assessment of such matters when the directors are assisted by independent counsel, it would appear that an

52. See Sarbanes-Oxley Act of $2002 \S 307$ (including those who transact business with SEC, represent those being investigated by SEC or prepare or participate in preparation of any document, notice, etc. believed to be filed with SEC, and advise person that statement need not be filed with SEC).

53. Id. $\$ 307(1)$.

54. For the Author's proposal, see supra note 48 and accompanying text. 
equally compelling case can be made for requiring independent counsel in any material conflict of interest transaction coming before the board or one of its committees.

\section{Tearing a Page from the Enron Play Book}

The inspiration for this Symposium issue was Enron and the other parade of financial scandals that captured national attention in 2002. When Enron filed for bankruptcy in late 2001, it was the largest bankruptcy in history. There will be many accounts for why Enron failed. What is significant from a public policy perspective regarding its failure was how unprepared the financial markets were for its demise. It was only in the few months before its collapse that warning signals were appearing in the press. Equally disturbing is that its board of directors was unaware of its problems and the level of harmful opportunism by Enron's managers who were connected with some of the events that projected the company into bankruptcy. Certainly the board's surprise, and likely that of financial markets, would have been of a lower order if the suggestions advanced here were followed.

As is well-known by now, Enron had engaged in a massive campaign to relocate its liabilities from its financial statements through nearly three thousand special purpose entities. Enron's campaign was made possible by the alchemy of accounting's consolidated reporting standards. Generally Accepted Accounting Principles required that to avoid an entity being consolidated with the financial reports of Enron, Enron or its managers could not have more than a three percent ownership interest in the entity. ${ }^{55}$

The thesis advanced here and Enron are linked by the few instances in which the Enron board was called upon to waive the company's strict prohibition of conflict of interest transactions between Enron and its senior management. It so happened that some members of its senior management team held an equity interest in a few of the most significant special purpose entity transactions. One of Enron's outside law firms, which received seven percent of its total revenues from Enron, ${ }^{56}$ orchestrated the presentation to the board at which Enron's Code of Ethics was waived and the self-dealing transactions involving the special purpose enti-

55. Sadly, the rules for consolidated reporting have not been updated for several decades by the Financial Accounting Standards Board. So much of the primary guidance for Enron's reporting were standards and ambiguous lore that were several decades old. Most significantly, the source for the three percent test is a rather vague statement by the SEC's staff that the minimum acceptable investment by an independent owner should be three percent. See William Powers Jr. et al., Report of Investigation by the Special Investigative Committee of the Board of Directors of Enron Corp. 38-39 (Feb. 1, 2002), available at 2002 WL 198018 [hereinafter Powers Report].

56. See Julie Mason, Houston Law Firm Probed for Role in Fall of Enron, Hous. Chron., Mar. 14, 2002, at A13 (billings of $\$ 36$ million represented about seven percent of firm's revenues). 
ties were approved. The board was not informed in that presentation that some of the law firm's partners had misgivings about whether the transaction satisfied the three percent test and had even broader concerns about the wisdom of the transaction. ${ }^{57}$ Moreover, the board was not advised of the substantial gains that the participating managers could garner, regardless of whether any gains flowed to Enron. ${ }^{58}$

We will, of course, never know whether the Enron board or Enron itself would have performed better if it was not advised on these conflict of interest transactions by a firm that had no historical relationship to Enron's senior management team. ${ }^{59}$ We can say with confidence that if the board was called upon to consider whether to sue the interested managers for misconduct in connection with those transactions, the law would have compelled that the outside directors be advised by a firm that did not earn seven percent of its annual revenues from Enron. Moreover, outside directors, despite their respect for the reputation of the firm's outside counsel, should appreciate the great difficulty that counsel is placed in when it finds itself between the board and the self-dealing managers. A wise

57. See Ellen Joan Pollock, Limited Partners: Lauyers for Enron Faulted Its Deals, Didn't Force Issue, WALL ST. J., May 22, 2002, at A1 (reporting that partners for Enron's outside law firm had objected to Enron's general counsel, but not to its board of directors, to many of arrangements in which senior management had financial interest on ground they were not in Enron's best interests).

58. The special purpose entities bore a variety of colorful names. In the transaction involving the Executive Committee of the Board's approval of "Chewco," the directors were not informed that Michael J. Kopper, a subordinate of Andrew Fastow, Enron's chief financial officer, had a material financial interest in the special purpose entity and that he stood to reap significant financial gains as a result of that interest. See Powers Report, supra note 55, at 149 ("The minutes and the interviews we conducted do not reveal any disclosure to the Executive Committee of Kopper's role .... Each [Kopper and Fastow] had an obligation to bring Kopper's role to the Committee's attention."). The Powers Report rarely touches upon the involvement or even the presence of outside counsel in the board or its committee's engagement of transactions that were the focus of the special investigative report. Thus, it is not possible to speculate whether there were instances in which the outside counsel were present when the directors were deliberating a matter and the attorneys forbore sharing their misgivings or other information with the outside directors. The press does report that Enron's outside law firm was present at the meeting when the directors were considering Chewco and their misgivings regarding whether Chewco satisfied the three percent outside equity ownership required to avoid consolidating its results with those of Enron. See Carrie Johnson, House Panel to Question Enron's Attormeys, WASH. POST, Mar. 14, 2002, at E1.

59. Two special purpose entities involving Mr. Fastow were LJM1 and LJM2 (from which he ultimately reaped gains of $\$ 45$ million). See Pollock, supra note 57 , at Al. Even though the board was called upon in allowing LJM1 and LJM2 to go forward to waive its Code of Ethics' bar to conflicts of interest involving senior management, it did not "obtain detailed information about Fastow's compensation from the financial interest in the transactions." See Powers Report, supra note 55, at 151. The board did, however, adopt a series of procedures to monitor the performance of these two entities so as to address the conflicts of interests. See id. at 152-59 (discussing creation of LJM1 and LJM2 and actions of Audit and Finance Committee). 
Cox: $M$ anaging and M onitoring Conflicts of Interest: Empowering the Out

2003] Managing and Monitoring Conflicts of Interest 1095 course of action is to vent some possible steam out of the relationship by the board retaining an independent counsel. 
Villanova Law Review, Vol. 48, Iss. 4 [2003], Art. 4

1096

Vili.anova Law Review

[Vol. 48: p. 1077 